\title{
Determinants of international activity: evidence from the chemical processing industry
}

\author{
Andrea Fosfuri ${ }^{\mathrm{a}, \mathrm{b}, *}$ \\ a Department of Business Administration, Universidad Carlos III de Madrid, \\ Calle Madrid 126, Getafe - Madrid 28903, Spain \\ b CEPR, London
}

\begin{abstract}
This paper empirically investigates two important determinants of international activity through wholly owned operations, joint-ventures and technology licensing, namely country risk and intellectual property rights (IPRs) protection. Using a comprehensive database on investments in chemical plants during the period 1981-1996, we show that higher levels of country risk are associated with less activity into recipient economies. The analysis also suggests that international activity with smaller resource commitment tends to be preferred in countries with higher levels of risk, and that multinational investment is more responsive to changes in risk conditions than indigenous investment. After controlling for several country characteristics, we do not fin IPRs protection playing a significan role in fostering international activity or conditioning its mode.
\end{abstract}

JEL classification: F21; F23; O32; O34

Keywords: Foreign direct investment; Technology licensing; Country risk; IPRs protection; Chemical processing industry

\section{Introduction}

The past decade has been marked by the upsurge of firms involvement outside national borders. The 2002 World Investment Report shows that the worldwide $\mathrm{fl} \mathrm{w}$ of foreign direct investment has passed from

\footnotetext{
* Tel.: +3491624 9351; fax: +34916249608.

E-mail address: andrea.fosfuri@uc3m.es.
}

slightly more than $\$ 200$ billion in 1992 to about $\$ 700$ billion in 2001. Arora et al. (2001) have stressed the increased importance of market-based transactions for technology in the last two decades of the XX century. Their estimates indicate a worldwide market for technologies in the range of $\$ 35-50$ billion, of which a large chunk is due to cross-border deals. International alliances and joint-ventures have also become widespread in the last few years. 
From a strategic point of view, since the need to exploit technological assets outside national borders has become more and more imperative, companies must have a good understanding of trends in international expansion. From a policy point of view, governments seeking to attract international technology must be concerned about the factors that enhance or hinder foreign direct investment and licensing, which are leading channels through which technology moves across borders. This papers focuses on two important determinants of international activity through wholly owned operations, joint-ventures and technology licensing, namely country risk and intellectual property rights (IPRs) protection.

Although all business transactions involve some degree of risk, when they occur across international borders they carry additional risks not present in domestic transactions. Country risk analysis rests on the fundamental premise that growing imbalances in economic, social, or political factors increase the risk of shortfall in the expected return of an investment. The available evidence shows that many countries have experienced important changes in their idiosyncratic risk during the 1990s. Indeed, countries like Yugoslavia and Iraq have more than doubled their level of risk. Similarly, countries like Indonesia, Cameroon, Pakistan and Algeria have experimented very significan increases. On the other side, Poland, El Salvador, Peru, Costa Rica and Panama have more than halved their level of country risk. $^{1}$

Firms, and managers in particular, seem to place a lot of attention on the changes of investment conditions in different countries. Anecdotal facts suggest that rises in country-specifi risk have an immediate effect on international investment that is often considered footloose and ready to move to safer places. The proliferation of country ratings, which should serve as an aid to decision-making in the assessment of country risks, and the rise of specialized consultancy companies, like Control Risks Group, provide further evidence of the close relationship between international investment and country-specifi risk.

\footnotetext{
${ }^{1}$ These figure are obtained by comparing the Institutional Investor Credit Ratings (IICR) of the different countries at the beginning of the year 1990 and at the end of 1999. See later for details on the IICR.
}

The main objective of this paper is to offer a closer look at the impact of country risk on the international activity of multinational firms By exploiting a comprehensive data set on plant-level investments in the worldwide chemical processing industry during the period 1981-1996, we are able to distinguish between three modes of international expansion: wholly owned operations, joint-ventures and technology licensing. ${ }^{2}$ We account for the simultaneity of the mode choice. In addition, we estimate the relative effect of country risk on wholly owned operations, joint-ventures and technology licensing, and disentangle the impact of country risk on investments by local and multinational firms

The second objective of this research is to address the ongoing debate on the importance of policies aimed at stricter enforcement of IPRs. Advocates of these policies argue that stronger IPRs protection would enhance technology fl ws and foreign downstream investment in the recipient countries. This view has been echoed in the introduction of the Agreement on Trade-Related Aspects of Intellectual Property Rights (TRIPs). Opponents suggest that stricter enforcement of IPRs would reinforce the monopoly power of large multinational corporations. Indeed, many developing economies are not eager to strengthen their IPR legislation and its enforcement fearing that the losses resulting from this action would outweigh the benefits After controlling for other country characteristics, our results show that, at least for the chemical processing industry, international activity through wholly owned operations, joint-ventures and technology licensing does not seem to be sensitive to the degree of protection of IPRs. At the very least, this suggests that further research is needed to support either of the two sides of the debate.

\section{Related literature and contribution}

The main contribution of this paper is to provide a systematic and econometrically sound investigation of two important determinants of international activity: country risk and IPRs protection.

\footnotetext{
${ }^{2}$ The chemical processing industry constitutes an ideal test-bed for addressing our research questions since it is a global technologybased industry. Moreover, the amount of investment to start up a chemical plant is substantial, which makes country risk analysis more important. In addition, the industry has developed a long tradition of technology licensing.
} 
There is an empirical literature focused on country risk as an explanatory factor for the amount of foreign direct investment in a given country. However, little is known about other channels of international expansion, most notably technology licensing. We also distinguish between wholly owned operations and joint-ventures. One of the firs studies that analyzed the relationship between risk and foreign direct investment is Flamm (1984). He estimates an equation relating multinational electronics investments to relative wages, using country-specifi dummy variables as proxies for differential risk. His results seem to suggest that firm are very much concerned with having a balanced risky portfolio so they respond quickly to changes in country risk. Wheeler and Mody (1992) also investigate the impact of country-specifi risk on foreign direct investment. They measure risk as a firs principal component extracted from a set of indices which measure political stability, inequality, corruption, red tape, quality of the legal system, cultural compatibility, attitude toward foreign capital and general expatriate comfort. They fin that firm seem to assign little importance to perceived risk, except for some modest weight attached to geopolitical considerations. Bevan and Estrin (2000), using a panel data set containing information on foreign direct investment $\mathrm{fl}$ ws from 18 market economies to 11 transition economies over the period 1994-1998, fin that foreign direct investment infl ws are strongly influence by country risk, among other factors. More recently, Alburquerque (2003), using aggregate data on investment in a large set of countries, shows that the share of foreign direct investment infl ws to gross fl ws is negatively correlated to several creditworthiness and country risk ratings. He argues that foreign direct investment is harder to expropriate than other financia $\mathrm{fl}$ ws. However, he does not provide estimates of the impact of country risk on the absolute volume of foreign direct investment.

Our paper shows that the whole $\mathrm{fl} \mathrm{w}$ of international activity into a recipient economy is negatively related to the level of country risk. Moreover, this effect holds for all three modes considered in our analysis, namely wholly owned operations, joint-ventures and technology licensing. In addition, we are also able to show that the relative effect is stronger for modes that involve greater commitment with the recipient country, such as wholly owned operations. In sum, higher levels of country risk mean less international activity, which tends to be more market-based. Finally, we disentangle the impact of country risk on investments by local and multinational firms and show that international investment tends to be more footloose and ready to move to safer places.

This paper also contributes to the growing literature on international technology transfers and IPRs protection. The finding of this literature have been mixed so far (Maskus, 1998). For instance, Lee and Mansfiel (1996) report a positive and significan impact of IPRs on foreign direct investment fl ws. However, Fink (1997) shows that, if it exists at all, the relationship between IPRs and multinational activity is negative. Few studies have addressed the link between other means of international technology transfers and IPRs. Smith (2001) shows that IPRs have a positive and significan effect both on foreign direct investment and licensing. The effect is more pronounced for licensing and tends to be stronger in countries with strong imitative abilities. However, Branstetter et al. (2002) fin no evidence of an increase in technology licensing to unaffiliate parties due to stricter enforcement of IPRs, and Maskus et al. (2003) report that in lower-technology industries it is more likely that stronger IPRs would induce firm to shift toward lesser use of licensing. In our paper, we cannot fin any significan relationship between the strength of IPRs protection and the $\mathrm{fl}$ ws of international activity, irregardless of the mode chosen by the investor.

Two important limitations should be noted. First, we do not have exports figures so our analysis is limited to international expansion modes that imply the transfer of production to the recipient country. A fir could exploit its technological advantage abroad simply by producing at home and serving the foreign market through exports. Second, we have data from only one industry, so that the extent to which our results can be exported to other industries remains unclear. ${ }^{3}$

\footnotetext{
3 The lack of exports figure might not be a serious problem in the chemical processing industry where the key upstream input - technology - is easier to move across locations, while the fina products (chemicals such as ammonia and ethylene) are costly to transport. Concerning the applicability of our results to other industries, we believe that they should be extendable to other global high-tech industries (for instance, electronics). The test of this conjecture is left to future research.
} 


\section{Theoretical background and hypotheses}

Most theoretical research on firms internationalization builds on the premise that firm have assets that confer them an advantage in servicing a foreign market (Hymer, 1976). Such assets include intangibles such as knowledge and technology. Firms firs decide whether to serve the foreign market through exports or by locating the production abroad. Once the decision to locate the production abroad is taken, firm have several modes available to organize their international activity, among them, wholly owned operations, joint-ventures and technology licensing (Dunning, 1981; Markusen, 1995). In this paper, we will focus only on international activity that implies the transfer of production in the foreign country.

The relationship between risk and the level of international activity in a country is straightforward. Other things being equal, higher country risk reduces the expected profit from international investment and hence the propensity to invest (Wheeler and Mody, 1992). So, one should expect a reduction in the expected profits of any of the three forms of international expansion analyzed here. ${ }^{4}$ This is straightforward in the case of wholly owned operations, where the investor is the residual claimant of all possible profits and in the case of joint-ventures, where the investor typically receives a share of the whole profits but it is also true for technology licensing, where royalties and other types of payments tend to be, although spuriously, related to the expected profit obtainable through the exploitation of the technology.

Let the outside best option for the investor (it could be not serving at all a given foreign market or exporting) be independent of (or less respondent to) changes in country risk, then the following proposition follows immediately:

Proposition 1. The flow of international activity into a given country is negatively related to the level of country risk.

\footnotetext{
${ }^{4}$ Alburquerque (2003) shows that foreign direct investment has a sharing risk advantage over other capital $\mathrm{fl}$ ws because an important component of foreign direct investment is due to intangible assets that are inalienable to a large extent. This makes foreign direct investment less sensitive to country risk vis-à-vis other financia fl ws.
}

Notice that this does not imply that the fl w of each of the three forms of international activity considered here increases when the level of country risk decreases. In fact, the relative effect of changes in the level of country risk is more subtle. The three modes involve a very different level of resource commitment (Dunning, 1981; Hill et al., 1990). By resource commitment we mean dedicated assets that cannot be redeployed to alternative uses without cost (loss of value). These assets may be tangible (e.g. physical plant) or intangible (e.g. management know-how). In the case of technology licensing, the licensee bears most of the costs of opening up and serving the foreign market. In the case of a wholly owned operation, the investor has to bear all of the costs. The level of resource commitment consistent with a joint-venture will fall somewhere between these two extremes.

Where country risk is high, the investor might be well advised to limit its exposure to it by reducing its resource commitments and increasing its ability to exit from the market quickly without taking a substantial loss should the environment worsen. This suggests that, other things being equal, technology licensing and joint-ventures will be favored over wholly owned operations when country risk is high. In turn, this implies that higher country risk has a negative effect on the $\mathrm{fl} \mathrm{w}$ of wholly owned operations. The effect on joint-ventures and technology licensing is less clearcut. For instance, consider technology licensing. On the one hand, we have argued above that the expected profit from technology licensing tend to reduce with risk, as do the incentives to employ this mode of international expansion. On the other hand, higher risk might force firm willing to exploit their technological assets internationally to opt for modes with reduced resource commitment. In other words, with higher levels of country risk, technology licensing becomes relatively more appealing than wholly owned investment. This latter effect increases the fl $\mathrm{w}$ of licensed technology. The net result is ambiguous and technology licensing $\mathrm{fl}$ ws theoretically might either increase or decrease with country risk. This is therefore an empirical question that we will address with the data. What is unambiguous is that the coefficien of country risk on technology licensing fl ws must be smaller than the coefficien of country risk on fl ws of wholly owned operations. A similar argument could be put forward for joint-ventures that, as far as resource commitment, 
fall somewhere between wholly owned operations and technology licensing.

Proposition 2. The impact of changes in country risk on the flow of wholly owned operations is larger than the impact on the flow of joint-ventures that, in turn, is larger than the impact on the flow of technology licensing.

That multinational investment responds negatively to increasing degrees of country risk is, although correct, not too surprising in the light of historical evidence and industrial practice. Perhaps more interesting is the asymmetry between local and international investments in the response to changes in risk conditions. Indeed, all business transactions involve some degree of risk. However, when business transactions occur across international borders, they carry additional risks not present in domestic transactions. Anecdotal facts suggest that rises in country-specifi risk have an immediate effect on international investment which is often considered more footloose and able to move to safer places. There are at least three possible arguments that can justify this position: First, local firm have a better understanding of country idiosyncrasies, so they are better equipped to manage risk. Second, their resource commitment might be substantially smaller than the one a foreign fir needs to undertake. Finally, their outside investment options are probably less interesting, so they would undertake riskier investments or ones with smaller expected benefits We can therefore state the following:

Proposition 3. Multinational investment is more responsive to changes in country risk than local investment.

As far as IPRs are concerned the absolute effect of changes in the strength of protection on any form of international activity considered here is far from being theoretically clear-cut. On the one hand, stronger IPRs provide legal recourse against imitation by foreign firm and thus, make more appealing the exploitation of technological assets abroad. This is known as the "market expansion effect". On the other hand, stronger IPRs also confer to the foreign fir more market power, which can be exploited by reducing the supply of products, by rising the price, and restricting the investment in the recipient country. This is known as the "market power effect". See Smith (2001) for further discussion. There is more consensus in the literature about the relative impact of stricter enforcement of IPRs on the use of different modes. The reference framework here is the so-called "eclectic paradigm" (Dunning, 1981). Such a paradigm suggests that, once a fir has decided to locate production abroad, the choice between different entry channels, most notably, foreign direct investment and technology licensing, depends of what Dunning labels "internalization advantages". Applying the insights of the transaction cost theory (Williamson, 1991), this approach suggests that, absent significan contracting hazards, the 'default' low-cost governance mechanism is a simple contract. However, writing and executing a reliable contract for the use of technology requires adequate specificatio of property rights, monitoring and enforcement of contractual terms - any of which may be problematic. Stronger IPRs favor market-based transactions such as licensing because they force firm to better codify their knowledge in order to benefi from the protection of the intellectual property (Arora and Gambardella, 1994), reduce transaction costs by moderating the risk of opportunistic behavior by the licensees (Teece, 1986), and are a necessary condition for the rise of specialized technology suppliers, which in turn constitute a stimulus to market-based transactions in technology (Arora et al., 2001). However, two recent papers have defie this traditional wisdom. Arora and Ceccagnoli (2004) argue that on the one hand, stronger IPRs increase the efficien y of licensing contracts and thus the net surplus captured by the patent holder, but on the other hand, enhance the value of innovation and thus raise the opportunity cost of licensing. The net effect is therefore ambiguous. Maskus et al. (2003) go even further and claim that stricter enforcement of IPRs might reduce the use of licensing contracts in favor of wholly-owned investment in lower-technology industries.

\section{Model specification and data}

\subsection{Specification}

We assume that international activity through wholly owned operations, joint-ventures and technol- 
ogy licensing is a function of a set of variables which should account for the demand in a given country, of risk conditions, of the degree of IPRs protection and of some control parameters.

Among the country variables we include income per capita, population and distance. These three variables are intended to capture respectively for relative endowments, market size and transportation costs. Markusen (1995) provides a survey of models that generate these core explanatory variables.

As control parameters, we have considered the country level of education and the country openness to trade. ${ }^{5}$

We apply the following specification

$$
\begin{aligned}
\mathrm{TF}_{i j t}= & \alpha_{0} \mathrm{INCOME}_{i t}{ }^{\alpha_{1}} \mathrm{POP}_{i t}{ }^{\alpha_{2}} \mathrm{DIST}_{i}{ }^{\alpha_{3}} \mathrm{HUMAN}_{i t}{ }^{\alpha_{4}} \\
& \times \mathrm{OPEN}_{i t}{ }^{\alpha_{5}} \mathrm{R}_{i t}{ }^{\alpha_{6}} \mathrm{IPR}_{i t}{ }^{\alpha_{7}} \varepsilon_{i j t}
\end{aligned}
$$

where the subscripts $i$ denotes the country, $t$ the time period, and $j$ the mode (wholly owned, joint-venture or technology licensing). INCOME is the per capita income of the country, POP the population, DIST the weighted distance to capitals of world 20 major exporters, HUMAN a measure of the country level of education, OPEN openness to trade, $R$ country risk, IPR the degree of IPRs protection, and $\varepsilon_{i j t}$ a log normally distributed error term. $\mathrm{TF}_{i j t}$ is the $\mathrm{fl} \mathrm{w}$ of wholly owned operations, joint-ventures and technology licensing, respectively.

Taking natural logs of Eq. (1) one obtains the following:

$$
\begin{aligned}
\ln \left(\mathrm{TF}_{i j t}\right)= & \alpha_{0}+\alpha_{1} \ln \left(\mathrm{INCOME}_{i t}\right)+\alpha_{2} \ln \left(\mathrm{POP}_{i t}\right) \\
& +\alpha_{3} \ln \left(\mathrm{DIST}_{i}\right)+\alpha_{4} \ln \left(\mathrm{HUMAN}_{i t}\right) \\
& +\alpha_{5}\left(\mathrm{OPEN}_{i t}\right)+\alpha_{6} \ln \left(R_{i t}\right) \\
& +\alpha_{7} \ln \left(\mathrm{IPR}_{i t}\right)+\varepsilon_{i j t}
\end{aligned}
$$

\footnotetext{
${ }^{5}$ We have experimented with several other variables, like barriers to trade of capital goods, financia openness, country's latitude, dummy for major non-oil exporter, dummy for major oil exporter, dummy for major oil producer, capital account restrictions, etc. Most of them showed an insignifican coefficien and the inclusion or exclusion did not affect the results reported here. For brevity, we do not report these results, which are available from the author upon request.
}

Notice that we do not take the log of OPEN because this variable is a share. ${ }^{6}$

We expect positive parameters for INCOME and POP in all equations. The theoretical literature lacks consensus on whether transportation costs (DIST) and trade barriers (OPEN) increase or decrease international investments. For example, foreign direct investment or technology licensing might be a way to circumvent high transportation costs or barriers to exports (the so-called "tariff-jumping argument"; see Motta, 1992). However, models of complement behavior predict that conditions which decrease (increase) exports also decrease (increase) technology transfer modes which involve location in the foreign country (Smith, 2001). Finally, the sign of HUMAN is also ambiguous. The level of education might capture the "absorptive capacity" of the recipient country (Cohen and Levinthal, 1989). In this case, better educated workers available in the host country would facilitate both the creation of a wholly owned activity, the establishment of a joint-venture with a local partner and the transmission of technological knowledge to any potential licensee. However, higher level of education - better technological skills - might imply that local firm are better equipped for quickly imitating the technology of the foreign company. This means that the investor will try to protect its technology, reduce if possible any technological leakage, and ultimately restrict the amount of investment and technology transfer to the recipient country.

\subsection{Data}

Data on wholly owned operations, joint-ventures and technology licensing are obtained from Chemintell, a large commercial database on worldwide investments in chemical plants during the period 1981-1996. Chemintell is comprehensive, including almost the full population of chemical plants. For each chemical plant, the database reports both the name of the operating company and the name of the licensor when the technology used in the plant is bought from an unaffiliate source. In addition, it identifie when

\footnotetext{
${ }^{6}$ Both IPR and R are indexes which vary on a scale from 0 to 5 (with 5 meaning the highest level of IPRs protection) and from 0 to 100 (with 100 meaning the lowest level of country risk) respectively. For IPR we have used $\log (1+\mathrm{IPR})$. Since for $R$, the minimum value is 4.7 , we have simply taken the log.
} 
Table 1

Distribution of plants (number and value of investment) by geographic areas during the period 1981-1996 in the chemical industry (by the firm of our sample)

\begin{tabular}{|c|c|c|c|c|c|c|c|c|c|}
\hline & $\mathrm{AF}$ & EE & $\mathrm{FE}$ & JAP & $\mathrm{ME}$ & NA & SA & WE & Total \\
\hline \multicolumn{10}{|l|}{ WO } \\
\hline Number & 75 & 15 & 562 & 120 & 27 & 988 & 316 & 1195 & 3298 \\
\hline Value & 8.0 & 1.0 & 53.9 & 5.2 & 3.5 & 71.1 & 32.2 & 63.4 & 238.3 \\
\hline Share & 34 & 5 & 38 & 39 & 9 & 82 & 57 & 73 & 55 \\
\hline \multicolumn{10}{|l|}{ JV } \\
\hline Number & 19 & 52 & 303 & 72 & 92 & 46 & 57 & 105 & 746 \\
\hline Value & 2.0 & 3.5 & 29.1 & 3.1 & 12.1 & 3.3 & 5.8 & 5.6 & 64.5 \\
\hline Share & 9 & 19 & 20 & 23 & 32 & 4 & 10 & 6 & 13 \\
\hline \multicolumn{10}{|l|}{ LIC } \\
\hline Number & 127 & 207 & 627 & 119 & 167 & 165 & 179 & 327 & 1918 \\
\hline Value & 13.6 & 14.1 & 60.2 & 5.1 & 21.9 & 11.9 & 18.3 & 17.3 & 162.4 \\
\hline Share & 57 & 76 & 42 & 38 & 59 & 14 & 33 & 21 & 32 \\
\hline \multicolumn{10}{|l|}{ Total } \\
\hline Number & 221 & 274 & 1492 & 311 & 286 & 1199 & 552 & 1627 & 5962 \\
\hline Value & 23.6 & 18.6 & 143.2 & 13.4 & 37.5 & 86.3 & 56.3 & 86.3 & 465.2 \\
\hline
\end{tabular}

Note: Value in billions of US dollars. AF: Africa; EE: Eastern Europe; FE: Far East (including Australia); JAP: Japan; ME: Middle East; NA: North America; SA: South America; WE: Western Europe.

the property of a given plant is shared among different firms In other words, using our database it is possible to track the entire set of wholly owned and co-owned plants in foreign countries and the whole $\mathrm{fl} \mathrm{w}$ of international technology licensing in the chemical processing industry during the period under study. The database also provides information about plant investment costs.

In order to identify the plants belonging to each mode of international activity, we have constructed a sample of large chemical firms Such firms given their large financial managerial and organizational capabilities, were likely to have the option to decide the preferred mode of activity in any recipient country. Small chemical firm and, in particular, specialized engineering firm (SEFs), which are also active in international technology licensing, have to restrict their strategy space to whether they want to license or not. Since we would like to consider a framework where the mode of international activity is a decision variable for the investor, our sample is better suited for the type of analysis we are going to perform.

Our sample includes all chemical firm from developed countries (Western Europe, USA and Canada, and Japan) which had, by the year 1988, more than $\$ 1$ billion in aggregate sales (the list of firm is obtained from Aftalion, 1991). Of this set of firm only $153 \mathrm{had}$ at least one international plant (either as owner, coowner or licensor) reported in Chemintell during the period under study (see Appendix A). Firms of our sample cover about $50 \%$ of all foreign direct investments and more than $30 \%$ of international technology licensing.

Table 1 shows the distribution of plants (number and value of the investment generated) by the firm of our sample across geographical areas during the period 1981-1996. Notice that technology licensing is the predominant mode in most third world areas (the only exception is South America). On the contrary, technology licensing accounts for less than $20 \%$ in most developed areas. Here, the exception is Japan where technology licensing accounts for about $40 \%$ of all international activity by the firm of our sample. ${ }^{7}$

There is also some variation across sub-subsectors. For instance, sub-sectors like Plastics and Industrial Gases show technology licensing as the predominant

\footnotetext{
7 There is also some variation across firms nationality. US and European firm (globally taken) tend to behave similarly with about $25 \%$ of licensing activity. Japanese firm have a stronger attitude towards technology licensing which accounts for $60 \%$ of their international activity.
} 
mode. On the other extreme, in Pharmaceuticals and Organic Chemicals wholly owned operations account for more than 90 and $75 \%$, respectively. This suggests that there might be factors related to the technology which could be lost at a country-level aggregation. Some technologies might be more standardized, easier to transfer through contracts (Kogut and Zander, 1993) or there might exist more competition in the licensing market (see Arora and Fosfuri, 2003). All these factors favor a more extensive use of technology licensing. We will try to partially control for this technology-specifi heterogeneity in our regressions in Section 5.

We aggregate our data in four time periods: 1981-1983, 1984-1987, 1988-1991, 1992-1996. ${ }^{8}$ Hence, we use the subindex $t=1,2,3,4$ for each of the four periods, respectively. There are three reasons for such aggregation. First, some country variables do not basically show variability from one year to another. Second, it typically takes several months or years from the decision to build a chemical plant to the completion of the investment. So, investment decisions tend to be correlated to long term rather than short term changes in country conditions. Third, in many countries (especially, the smaller ones) and for many years the fl ws of international activity would be zero.

Our dependent variable is the $\mathrm{fl} \mathrm{w}$ of international activity by the firm of our sample in a given country and in a given time period. As discussed above we distinguish between wholly owned operations, jointventures and technology licensing.

All our explanatory variables that have time variability are measured at the beginning of each time period. The only exception is our measure of IPRs which is only available for the year 1980, 1985, 1990 and 1995 (we have, therefore, assumed that these correspond respectively to our four periods).

We use a set of 75 countries for which we could collect comparable data on the characteristics described

\footnotetext{
${ }^{8}$ There are respectively 1507, 1599, 2090 and 744 international plants by the firm of our sample in each period. The smaller number of plants in the last period is more likely to be due to misrepresentation in Chemintell rather than a reduction in the pace of international investment. Indeed, the shares of wholly owned investments, jointventures and technology licensing remain quite stable across all periods. As a robustness check we have excluded the last period from our analysis, and experimented with slightly different time periods. Results only change marginally.
}

above. The list of countries is reported in the appendix. We have therefore a panel of 300 observations. Notice that the cross-time variability is quite modest for some country variables (like for instance IPR). For others, like $R$, is much more important.

For INCOME, POP and OPEN we have used the Penn world tables (which are available on-line at http:// datacentre.chass.utoronto.ca/pwt/). DIST and HUMAN have been obtained from Barro and Lee (1994). (Available on-line at http://www.nuff.ox.ac.uk/Economics/Growth/barlee htm.)

We measure the strength of IPRs using an index developed by Ginarte and Park (1997). ${ }^{9}$ This index uses a coding scheme applied to national patent laws, where fi e categories are considered: extent of coverage, membership in international patent agreements, provisions for loss of protection, enforcement mechanisms and duration of protection. It has been extensively used in previous studies (see, among others, Smith, 2001; Oxley, 1999; Smarzynska, 2003). One limitation of this measure is that it is based on statutory protection, which might actually differ from the real protection (whether patent laws are enforced or not). We have also experimented with the index developed by Rapp and Rozek (1990). This index is only available for the mid 80s and reflect the conformity of national patent laws with minimum standards proposed by the US Chamber of Commerce. Both indexes are highly correlated and using one instead of the other does not affect any of the results.

As a proxy of country risk we use the Institutional Investor Credit Ratings (IICR). Institutional investor credit ratings are based on a survey of leading international bankers who are asked to rate each country on a scale from zero to 100 (where 100 represents maximum creditworthiness). Factors which are taken into consideration in this measure include the economic and political outlook, debt service, financia reserves, fis cal policy, access to capital market, trade balance and investments. To assess the sensitivity of the results we also use a weighted average of the political, economic and financia risks developed by the Political Risk Services' International Country Risk Guide (ICRG). This measure is only available starting from the mid 1980s

\footnotetext{
${ }^{9}$ I would like to thank Professor Walter Park for kindly supplying the measure of patent protection used in this paper.
} 
Table 2

Variables and sources

\begin{tabular}{|c|c|c|}
\hline Variable & Description & Source \\
\hline $\mathrm{ALL}_{i t}$ & $\begin{array}{l}\text { Investment in country } i \text { and period } t \text { generated by the international activity } \\
\text { of our sample firm (in millions of US dollars) }\end{array}$ & Chemintell (1996) \\
\hline $\mathrm{WO}_{i t}$ & $\begin{array}{l}\text { Investment in country } i \text { and period } t \text { generated by wholly owned operations } \\
\text { of our sample firm (in millions of US dollars) }\end{array}$ & Chemintell (1996) \\
\hline $\mathrm{JV}_{i t}$ & $\begin{array}{l}\text { Investment in country } i \text { and period } t \text { generated by joint-ventures of our sample } \\
\text { firm (in millions of US dollars) }\end{array}$ & Chemintell (1996) \\
\hline $\mathrm{LIC}_{i t}$ & $\begin{array}{l}\text { Investment in country } i \text { and period } t \text { generated by technology licensing of } \\
\text { our sample firm (in millions of US dollars) }\end{array}$ & Chemintell (1996) \\
\hline $\mathrm{SEF}_{i t}$ & $\begin{array}{l}\text { Investment in country } i \text { and period } t \text { generated by technology licensing of } \\
\text { specialized engineering firm (in millions of US dollars) }\end{array}$ & Chemintell (1996) \\
\hline LOCAL $_{i t}$ & Investment in country $i$ and period $t$ by local firm (in millions of US dollars) & Chemintell (1996) \\
\hline $\mathrm{INCOME}_{i t}$ & $\begin{array}{l}\text { (Real) income per capita in country } i \text { at the beginning of period } t \text { (in US } \\
\text { dollars) }\end{array}$ & Penn World Table \\
\hline $\mathrm{POP}_{i t}$ & Population of country $i$ at the beginning of period $t$ (in thousands) & Penn World Table \\
\hline $\operatorname{DIST}_{i}$ & $\begin{array}{l}\text { Weighted distance of country } i \text { 's capital to capitals of } 20 \text { major exporters (in } \\
\text { kilometers) }\end{array}$ & Barro and Lee (1994) \\
\hline HUMAN $_{i t}$ & $\begin{array}{l}\text { Averaged schooling years in the total population over age } 25 \text { in country } i \text { at } \\
\text { the beginning of period } t\end{array}$ & Barro and Lee (1994) \\
\hline $\mathrm{OPEN}_{i t}$ & $\begin{array}{l}\text { (Exports }+ \text { imports)/GDP at current international prices in country } i \text { at the } \\
\text { beginning of period } t\end{array}$ & Penn World Table \\
\hline $\mathrm{IPR}_{i t}$ & $\begin{array}{l}\text { Strength of patent protection in country } i \text { at period } t \text {. This is an index which ac- } \\
\text { counts for the extent of patent coverage, membership in international patent } \\
\text { agreements, provisions for loss of protection, enforcement mechanisms and } \\
\text { duration of protection }\end{array}$ & Ginarte and Park (1997) \\
\hline$R_{i t}$ & Global index of risk in country $i$ at the beginning of period $t$ & Institutional Investor Credit Rating \\
\hline$R_{i t}^{2}$ & $\begin{array}{l}\text { Composite index of risk (political, financia and economic) in country } i \text { at } \\
\text { the beginning of period } t\end{array}$ & Erb et al. (1996) \\
\hline DWEAK $_{i}$ & $\begin{array}{l}\text { Dummy variable that takes the value of one if the country has less than } 500 \\
\text { scientists and engineers per million of population and zero otherwise }\end{array}$ & Statistical Yearbook (UNESCO) \\
\hline DSTRONG $_{i}$ & $\begin{array}{l}\text { Dummy variable that takes the value of one if the country has more than } 500 \\
\text { scientists and engineers per million of population and zero otherwise }\end{array}$ & Statistical Yearbook (UNESCO) \\
\hline Time fi ed effects & $\begin{array}{l}\text { Dummy variables for the following time periods: } 1981-1983,1984-1987 \text {, } \\
1988-1991,1992-1996\end{array}$ & Chemintell (1996) \\
\hline
\end{tabular}

and it is highly correlated with the Institutional Investor Credit Ratings. ${ }^{10}$ We fin that our results are robust with respect to the choice of measure. Regressions are available from the author upon request. The Institutional Investor Credit Ratings have been used by Bevan and Estrin (2000) to assess the impact of country risk on foreign direct investment in a set of transition economies. Other papers, like Wheeler and Mody (1992), have used more complex measures of country risk. We favor an approach in which the country risk is proxied by information actually available to firm at

\footnotetext{
10 The correlation (computed over 72 countries and 3 time periods) is above 0.9 . Alternative measures of country risk, like the one developed by Euromoney and the Moody's ratings, are also highly correlated with the Institutional Investor Credit Ratings.
}

the time of the investment decision - the credit ratings - which can be purchased commercially.

Finally, we include dummy variables to control for time period fi ed effects. For completeness, we also add a specificatio that includes country-specifi random effects.

Table 2 summarizes our variables along with their sources, whereas Table 3 provides some basic descriptive statistics.

It is important to notice that some regressors tend to be correlated. In particular, the correlation between $R$, IPR, INCOME and HUMAN is always greater than 0.5 . However, a condition number test does not suggest that multicollinearity is a serious issue (Greene, 1993). 
Table 3

Descriptive statistics $(n=300)$

\begin{tabular}{lcccc}
\hline Variable & Mean & Std. dev. & Min. & Max. \\
\hline ALL $_{i t}$ & 1375.0 & 2598.3 & 0 & 16402 \\
WO $_{i t}$ & 783.5 & 1882.7 & 0 & 13924 \\
JV $_{i t}$ & 153.9 & 376.5 & 0 & 2772 \\
LIC $_{i t}$ & 437.7 & 998.1 & 0 & 12996 \\
SEF $_{i t}$ & 617.7 & 1109.5 & 0 & 7310 \\
LOCAL $_{i t}$ & 3331.5 & 7729.6 & 0 & 68600 \\
INCOME $_{i t}$ & 6730 & 5641 & 439 & 24518 \\
POP $_{i t}$ & 54390 & 153428 & 231 & 1164951 \\
IIST $_{i}$ & 5662 & 2562 & 1267 & 11500 \\
HUMAN $_{i t}$ & 5.3 & 2.7 & 0.9 & 12 \\
OPEN $_{i t}$ & 65.8 & 51.0 & 12.9 & 427.9 \\
IPR $_{i t}$ & 2.67 & 0.94 & 0 & 4.86 \\
$R_{i t}$ & 46.5 & 25.8 & 4.7 & 98.3 \\
$R_{i t}^{2}$ & $64.2^{\mathrm{a}}$ & 16.5 & 25.5 & 94.0 \\
DWEAK $_{i}$ & 0.427 & 0.495 & 0 & 1 \\
DSTRONG $_{i}$ & 0.573 & 0.495 & 0 & 1 \\
\hline
\end{tabular}

a Only available for 72 countries and 3 time periods.

Before turning to the empirical results, two important caveats about our explanatory variables are due here. First, whereas our dependent variables are measured at the country-industry level, all explanatory variables are measured at the aggregate country level. For instance, we are implicitly assuming that the level of education in the Chinese chemical industry corresponds

Table 4

OLS and Tobit estimations: $\mathrm{ALL}_{i t}$ to the level of education in China. Second, most of our explanatory variables are proxies for some underlying and typically unmeasurable phenomena. Some of these proxies might end up picking up different factors at once, and the interpretation of the estimates might turn difficult As a conservative approach, we have therefore tried to stay as close as possible to the related literature in the choice of our proxies.

\section{Empirical results}

Table 4 (model 1) reports the OLS estimation of Eq. (2) where the dependent variable is the logarithm of the sum of the investment generated by any of the three modes of international activity (wholly owned operations, joint-ventures and technology licensing) in country $i$ and period $t$. In other words, we are proxing the $\mathrm{fl} \mathrm{w}$ of international activity with the value of the investments in the recipient economy (i.e. the costs of setting up the chemical plants). As a sensitive check, we have also performed our analysis using the number of plants rather than their value. Results hold unchanged.

INCOME and POP have a positive and significan effect on the total fl $\mathrm{w}$ of international activity. DIST is positive, although not significant suggesting that transportation costs favor location of production in distant countries vis-à-vis exporting. OPEN is positive and

\begin{tabular}{|c|c|c|c|c|c|c|}
\hline & \multicolumn{2}{|l|}{ OLS: $\mathrm{ALL}_{i t}$} & \multicolumn{2}{|c|}{ TOBIT: $\mathrm{ALL}_{i t}$} & \multicolumn{2}{|c|}{ GLS random effects } \\
\hline & Model 1 & Model 2 & Model 1a & Model 2a & Model 1b & Model 2b \\
\hline Constant & $-27.48^{* * *}$ & $-30.010^{* * *}$ & $-33.73^{* * *}$ & $-37.18^{* * *}$ & $-14.34^{*}$ & $-14.49^{*}$ \\
\hline $\mathrm{INCOME}_{i t}$ & $1.144^{* * *}$ & $1.430^{* * *}$ & $1.499^{* * *}$ & $1.776^{* * *}$ & 0.402 & 0.369 \\
\hline $\mathrm{POP}_{i t}$ & $1.209^{* * *}$ & $1.270^{* * *}$ & $1.405^{* * *}$ & $1.574^{* * *}$ & $1.017^{* * *}$ & $1.014^{* * *}$ \\
\hline $\mathrm{DIST}_{i}$ & 0.444 & 0.267 & 0.416 & 0.202 & 0.081 & 0.154 \\
\hline HUMAN $_{i t}$ & $-0.605^{*}$ & -0.295 & $-0.852^{* *}$ & -0.453 & -0.552 & -0.628 \\
\hline $\mathrm{OPEN}_{i t}$ & $0.008^{* * *}$ & $0.009^{* * *}$ & $0.009^{* *}$ & $0.011^{* * *}$ & 0.006 & 0.006 \\
\hline $\mathrm{IPR}_{i t}$ & 0.384 & & 0.591 & & -0.130 & \\
\hline $\mathrm{DWEAK} \times \mathrm{IPR}_{i t}$ & & -0.012 & & 0.125 & & 0.005 \\
\hline $\mathrm{DSTRONG} \times \mathrm{IPR}_{i t}$ & & $0.902^{*}$ & & $1.278^{*}$ & & -0.250 \\
\hline$R_{i t}$ & $1.509^{* * *}$ & $1.538^{* * *}$ & $2.024^{* * *}$ & $2.043^{* * *}$ & $2.138^{* * *}$ & $2.085^{* * *}$ \\
\hline Number of obs. & 300 & 300 & 300 & 300 & 300 & 300 \\
\hline Left-censored & & & 85 & 85 & & \\
\hline Adjusted $R^{2}$ & 0.571 & 0.580 & & & & \\
\hline Log likelihood & & & -590.21 & -587.12 & & \\
\hline Wald $\mathrm{Chi}^{2}$ & & & & & 144.23 & 148.04 \\
\hline
\end{tabular}

Note: The regressions include dummies for time fi ed effects.

$$
\begin{array}{rl}
* & 10 \% . \\
* * & 5 \% . \\
* * * & 1 \% .
\end{array}
$$


Table 5

OLS estimations: $\mathrm{SEF}_{i t}$ and $\mathrm{LOCAL}_{i t}$

\begin{tabular}{|c|c|c|c|c|}
\hline & \multicolumn{2}{|l|}{$\mathrm{SEF}_{i t}$} & \multicolumn{2}{|l|}{$\mathrm{LOCAL}_{i t}$} \\
\hline & OLS & Tobit & OLS & Tobit \\
\hline Constant & $-28.91^{* * *}$ & $-17.37^{* * *}$ & $-20.52^{* * *}$ & $-20.77^{* * *}$ \\
\hline $\mathrm{INCOME}_{i t}$ & $0.946^{* * *}$ & $1.348^{* * *}$ & $0.748^{* * *}$ & $0.793^{* *}$ \\
\hline $\mathrm{POP}_{i t}$ & $1.279^{* * *}$ & $1.765^{* * *}$ & $1.103^{* * *}$ & $1.205^{* * *}$ \\
\hline $\operatorname{DIST}_{i}$ & $0.636^{* *}$ & $0.699^{*}$ & -0.069 & -0.157 \\
\hline HUMAN $_{i t}$ & -0.264 & -0.494 & -0.170 & -0.191 \\
\hline $\mathrm{OPEN}_{i t}$ & 0.004 & 0.006 & -0.003 & 0.003 \\
\hline $\mathrm{IPR}_{i t}$ & -0.312 & -0.059 & -0.123 & -0.079 \\
\hline $\mathrm{R}_{i t}$ & $0.800^{* *}$ & $1.065^{* *}$ & $0.820^{* *}$ & $0.948^{* *}$ \\
\hline Number of obs. & 300 & 300 & 300 & 300 \\
\hline Left-censored & & 102 & & 47 \\
\hline Adjusted $R^{2}$ & 0.536 & & 0.553 & \\
\hline Log likelihood & & -565.07 & & -619.57 \\
\hline
\end{tabular}

Note: The regressions include dummies for time fi ed effects.

$* 10 \%$.

** $5 \%$.

*** $1 \%$.

significant meaning that more open countries tend to attract larger $\mathrm{fl}$ ws of international activity. HUMAN shows a negative coefficient although barely signifi cant. At face value, this implies that the threat of imitation outweighs the importance of absorptive capacity. ${ }^{11}$

The coefficien of $R$ is positive and highly signifi cant. This implies that increases in the country credit ratings, our proxy for country risk, generate a larger fl w of international activity in the recipient economy. In dollar terms, this means that, in the average recipient country, a $10 \%$ increase in $R$ with respect to the mean (about 46) generates an increment in the chemical investment driven by international activity of about $\$ 200$ million per period. ${ }^{12}$ IPR is positive, but not at all significant At face value, this implies that IPRs protection does not play any role in conditioning the $\mathrm{fl} \mathrm{w}$ of international activity.

Since our sample includes mainly large firms one could argue that these large corporations are better able to insulate themselves against changes in the strength of IPRs protection and that the effect of IPR is mostly on small firms In Table 5, we address this possibility

\footnotetext{
${ }^{11}$ One could also argue that foreign firm are less likely to enjoy a technological advantage in countries with higher levels of human capital, implying a negative relationship between HUMAN and the $\mathrm{fl} \mathrm{w}$ of international activity.

12 This is obviously a lower bound of the total effect since we only consider large investors from developed countries.
}

by introducing a new dependent variable: $\mathrm{SEF}_{i t} . \mathrm{SEF}_{i t}$ is the investment in country $i$ and period $t$ generated by the licensing activity of specialized engineering firm (SEFs). SEFs are firm specialized in the design, engineering and sometimes licensing of chemical plants, but have no stakes in the product market. SEFs have usually a much smaller size than chemical firms Especially compared to the firm of our sample, SEFs are definitel small firms The results do not confir our conjecture that small firm are more sensitive to the protection offered by the patent system, and IPR remains not significant ${ }^{13}$

We have also performed a Tobit estimation (Table 4, model 1a) of Eq. (2). Indeed, about $30 \%$ of the observations for our dependent variable show no investment at all in a given country and for a given time period. A Tobit estimation should account for the truncated (at zero) dependent variable. Qualitative results hold unchanged. Finally, we report the results of the randomeffects GLS regression (Table 4, model 1b), in which the individual error terms are randomly distributed

\footnotetext{
${ }^{13}$ Many SEFs also specialize in construction services, and can provide "turnkey" plants to their customers. In addition, SEFs often act as licensing agents for chemical firms They offer complete technology packages consisting of the core technology licensed from chemical producers, along with know-how and installation and engineering services. In these cases, IPRs protection is likely to be less important.
} 
across cross-sectional units. The Lagrange multiplier test and the Hausman test suggest that there are countryspecifi random effects and that these are uncorrelated with the exogenous variables.

As we discussed in Section 3, the fact that IPR has no effect on international activity is not in contradiction with the theory. Indeed, stronger IPRs generate a market expansion effect and a market power effect. Since the former is positive and the latter is negative, the net effect is ambiguous. However, one can refin the theory a bit more. As suggested by Smith (2001), the risk of imitation is higher in countries with strong imitative abilities. Hence, one should expect that it is in these countries that the market expansion effect is stronger. Instead, in countries with poor imitative abilities an increase in IPRs protection would reinforce the market power of the investor and could possibly lead to a reduction in the $\mathrm{fl} \mathrm{w}$ of international activity.

In order to test this additional implication of the theory, we follow Smith's (2001) methodology and divide all our countries in two groups: countries with strong imitative abilities and countries with weak imitative abilities. We use the number of R\&D scientists and engineers to defin weak and strong imitative abilities. We construct two dummy variables: DWEAK, which takes the value of one if the country has weak imitative abilities (i.e. less than 500 scientists and engineers per million of population) and zero otherwise; DSTRONG, which takes the value of one if the country has strong imitative abilities (i.e. more than 500 scientists and engineers per million of population) and zero otherwise. Finally, we estimate an equation where these two dummies are multiplied by the variable IPR. Results are reported in Table 4, model 2 for OLS, model 2a for Tobit and model $2 b$ for GLS. As one can check, we do not fin any evidence of a significan impact of changes in IPRs protection on the $\mathrm{fl} \mathrm{w}$ of international activity in countries with strong imitative abilities. Instead, we do fin some weak evidence that countries with weak imitative abilities are recipient of more international activity when they implement a stricter enforcement of IPRs. This result is in contradiction with the theoretical argument illustrated above. We, however, take it with extreme caution because it not very robust and it disappears when we focus on each mode of international activity separately (see below).

We can now analyze the impact of our main explanatory variables on any single form of international ac-
Table 6

SUR estimations

\begin{tabular}{|c|c|c|c|}
\hline & $\mathrm{WO}_{i j}$ & $\mathrm{JV}_{i j}$ & $\mathrm{LIC}_{i j}$ \\
\hline \multicolumn{4}{|l|}{ Model 3a } \\
\hline Constant & $-37.447^{* * *}$ & $-35.273^{* * *}$ & $-24.856^{* * *}$ \\
\hline $\mathrm{INCOME}_{i t}$ & $0.795^{* * *}$ & $0.609^{* *}$ & $1.201^{* * *}$ \\
\hline $\mathrm{POP}_{i t}$ & $0.973^{\text {*** }}$ & $0.828^{* * *}$ & $1.159^{* * *}$ \\
\hline $\operatorname{DIST}_{i}$ & $0.974^{* *}$ & $1.213^{* * *}$ & 0.433 \\
\hline HUMAN $_{i t}$ & 0.205 & 0.092 & $-0.640^{*}$ \\
\hline $\mathrm{OPEN}_{i t}$ & $0.006^{* *}$ & 0.003 & 0.002 \\
\hline $\mathrm{IPR}_{i t}$ & 0.243 & -0.275 & -0.428 \\
\hline$R_{i t}$ & $1.960^{* * *}$ & $1.183^{* * *}$ & $0.945^{* * *}$ \\
\hline Number of obs. & 300 & 300 & 300 \\
\hline$R^{2}$ & 0.554 & 0.432 & 0.496 \\
\hline \multicolumn{4}{|l|}{ Model 3b } \\
\hline Constant & $-39.406^{* * *}$ & $-36.463^{* * *}$ & $-27.423^{* * *}$ \\
\hline $\mathrm{INCOME}_{i t}$ & $1.017^{* * *}$ & $0.743^{* * *}$ & $1.491^{* * *}$ \\
\hline $\mathrm{POP}_{i t}$ & $1.020^{* * *}$ & $0.857^{* * *}$ & $1.220^{* * *}$ \\
\hline $\operatorname{DIST}_{i}$ & $0.838^{* * *}$ & $1.130^{* * *}$ & 0.253 \\
\hline $\operatorname{HUMAN}_{i t}$ & 0.445 & 0.237 & -0.326 \\
\hline $\mathrm{OPEN}_{i t}$ & $0.007^{* *}$ & 0.003 & 0.003 \\
\hline DWEAK $\times \operatorname{IPR}_{i t}$ & -0.064 & -0.461 & -0.829 \\
\hline $\mathrm{DSTRONG} \times \mathrm{IPR}_{i t}$ & 0.644 & -0.031 & 0.099 \\
\hline$R_{i t}$ & $1.983^{* * *}$ & $1.196^{* *}$ & $0.974^{* * *}$ \\
\hline Number of obs. & 300 & 300 & 300 \\
\hline$R^{2}$ & 0.560 & 0.436 & 0.507 \\
\hline
\end{tabular}

Note: The regressions include dummies for time fi ed effects.

$* 10 \%$.

** $5 \%$.

$* * * 1 \%$.

tivity, taking into consideration the simultaneous character of the three modes. The empirical method is to estimate Eq. (2) for the three modes by means of seemingly unrelated regression (SUR) techniques. Table 6, model 3a, reports the results of the SUR estimations of Eq. (2).

Overall the results seem to confir the theoretical predictions discussed in Section 3. INCOME and POP are always positive and significan in all equations. DIST is positive, but significan only for the WO and JV equations, and OPEN is only significan and positive in the WO equation. The latter findin might suggest that more open countries tend to attract larger fl ws of wholly owned operations. HUMAN is not significan in any equation, but in the LIC equation where it takes a negative sign. As far as it concerns country risk, the focus of this paper, $R$ is positive and highly significan in all equations. The coefficien is considerably larger for the fl w of wholly owned operations, which support our hypothesis 2 . The coefficient of R in the LIC and 
Table 7

OLS estimations at the sub-sector level

\begin{tabular}{|c|c|c|c|c|c|}
\hline & Oil refinin & Petrochemicals & Plastics and rubber & Gas & Organic chemicals \\
\hline Constant & $-23.37^{* * *}$ & $-36.77^{* * *}$ & $-35.57^{* * *}$ & $-27.99^{* * *}$ & $-21.76^{* * *}$ \\
\hline $\mathrm{INCOME}_{i t}$ & $1.068^{* * *}$ & $1.272^{* * *}$ & $1.433^{* * *}$ & $0.990^{* * *}$ & 0.207 \\
\hline $\mathrm{POP}_{i t}$ & $0.891^{* * *}$ & $1.240^{* * *}$ & $1.328^{* * *}$ & $0.854^{* *}$ & $1.116^{* * *}$ \\
\hline $\operatorname{DIST}_{i}$ & 0.318 & $0.876^{* * *}$ & $0.713^{* *}$ & $0.626^{*}$ & 0.324 \\
\hline HUMAN $_{i t}$ & -0.301 & 0.111 & 0.010 & -0.038 & 0.048 \\
\hline $\mathrm{OPEN}_{i t}$ & $0.009^{* *}$ & 0.005 & $0.011^{* * *}$ & $0.008^{* *}$ & $0.008^{* *}$ \\
\hline $\mathrm{IPR}_{i t}$ & $1.013^{*}$ & -0.288 & -0.256 & 0.832 & 0.016 \\
\hline$R_{i t}$ & $0.806^{* *}$ & $0.820^{* *}$ & $0.667^{* *}$ & $0.876^{* *}$ & $1.642^{* * *}$ \\
\hline Number of obs. & 225 & 225 & 225 & 225 & 225 \\
\hline Adjusted $R^{2}$ & 0.396 & 0.530 & 0.592 & 0.431 & 0.532 \\
\hline
\end{tabular}

Note: The regressions include dummies for time fi ed effects.

$* 10 \%$.

** $5 \%$.

$* * * 1 \%$.

the JV equations are roughly similar (although bigger in the JV equation), suggesting that these two modes of international activity are equally affected by country risk. IPR does not have a significan effect in any of the three modes analyzed in this paper. Table 6 , model $3 b$, distinguishes between countries with strong imitative abilities and countries with weak imitative abilities. All coefficient remain basically unchanged. Our data do not seem to suggest that there exist a market expansion effect and a market power effect due to stronger IPRs. Indeed, the coefficien of IPR is never significant not even at the $10 \%$ level of confidence

Our fina hypothesis has to do with the different responses to changes in country risk conditions that one should expect from international and domestic investment. We argued that international investment, especially by large corporations, is much more footloose and able to move to safer places. To contrast this hypothesis, we have constructed another dependent variable, LOCAL $_{i t}$, which measures the investment in country $i$ and period $t$ by domestic enterprises. Table 5 reports the results of the OLS estimation of this new equation (along with the Tobit specification) The coefficien of $R$ is positive and significant However, its magnitude is much smaller than that of $R$ in the WO equation (Table 6 , model 3a) where the dependent variable is the investment in wholly owned plants in country $i$ and period $t$ by the firm of our sample (large chemical corporations). Overall, we can argue that our results suggest that higher degrees of country risk have an obvious negative effect on total investment. How- ever, this effect is relatively stronger for investment by large multinational corporations, which tend to shift to modes with less resource commitment, and relatively smaller for investment by local firms

One limitation of many studies that investigate the relationship between IPRs protection and international activity is that they aggregate $\mathrm{fl}$ ws of foreign direct investments and technology licensing across many diverse industries, some of which might not rely at all on the legal protection of intellectual property. By focusing on a single industry we clearly reduce this heterogeneity. Yet, the chemical industry is a vast sector that covers a myriad of different products from sophisticated drugs to fertilizers, from polymers to coal-based products. So far we have not tried to differentiate across different sub-sectors. However, there might be important differences. Indeed, for most process technologies in petrochemicals, basic plastics and industrial gases that had already matured by the 1980 s patents were probably much less a concern during the period under study. By contrast, patents could be much more important for drugs, specialty chemicals and new polymers. ${ }^{14}$

To better control for systematic differences across different chemical sub-sectors we have split our dataset in different groups which are meant to include products with similar characteristics. We have run separate re-

\footnotetext{
${ }^{14}$ Nevertheless, one should be aware that Chemintell only reports investment in plants, and it only deals with process technology. We do not have, for instance, product licensing, which is the major subject of transaction in pharmaceuticals.
} 
gressions for each group. Table 7 reports the results of our estimations for fi e main groups: oil refining petrochemicals, plastics and rubber, gas (which includes gas handling, air separation, and industrial gases), and organic chemicals (which includes explosives, textile and fibers food products, and pharmaceuticals). Our dependent variable is the logarithm of the sum of the investment generated by our three modes of international activity in any of the above mentioned groups. Notice that we have only three time periods since the sub-sector classificatio of Chemintell has changed after 1991. The sign of IPR is sometimes positive and sometimes negative, but almost never significant It is positive and significan at the $10 \%$ level only in the Oil Refinin equation. Contrary to what one could expect it is not significan in the organic chemicals equation, where pharmaceuticals is included. ${ }^{15}$

\section{Conclusions and discussion}

This paper has focused on country risk and IPRs protection as determinants of international activity by means of wholly owned operations, joint-ventures and technology licensing. We have shown that the whole fl $\mathrm{w}$ of international activity into a recipient economy is negatively related to the level of country risk. Moreover, this effect holds for all three modes considered in our analysis. The relative effect is stronger for modes which involve greater commitment with the recipient country, such as wholly owned operations. Finally, we have shown that multinational investment is more responsive to risk conditions than domestic investment.

By contrast, after controlling for other country characteristics, we do not fin evidence of a significan effect of IPRs protection on international activity. Although surprising, this findin has some plausible

\footnotetext{
15 As an additional effort to control for sources of heterogeneity across different chemical products, we have also explored a range of discrete choice models where the dependent variable is the probability, at the plant level, to choose among our three modes of international expansion. As regressors we employed the same country variables used in this paper along with a set of controls for products' and firms heterogeneity. Interesting enough, IPRs protection does not seem to be significan in conditioning the mode choice. We also fin that in countries with better risk conditions the probability that a foreign fir opts for a wholly owned plant is higher. For further details, see Fosfuri (2002).
}

justifications First, our measure of IPRs protection reflect mainly statutory protection that might actually differ from the real protection (whether patent laws are enforced or not). Second, as reported by Cohen et al. (2000), patents are considered by firm as one of the less effective means to protect their intellectual property. This is especially true for process innovations, the ones we consider in the paper. So, in light of their findings the fact that changes in patent protection do not affect international technology fl ws does not appear to be too surprising. Third, in a world where international treaties are becoming more enforced, a fir can sue for infringement in other jurisdictions (e.g. outside the host country). So, if the host IPRs regime is weak, the fir might still have recourse elsewhere (e.g. the WTO). Finally, even if IPRs protection affects neither the volume nor the composition of international activity, it might still affect the type of technology that is transferred. Firms might respond to lower levels of IPRs protection by transferring older vintage technologies (Fosfuri, 2000). With our data, we are not able to investigate this possibility.

At face value, our results suggest that governments in less developed countries keen to attract foreign investment and technology should pay greater attention to the quality of the business environment and to investment conditions rather than offering more statutory protection to IPRs. Needless to say, improving country risk conditions is neither easy nor rapid. A statutory change in IPRs protection or the formal participation to an international IPRs agreement are much easier policies to implement. However, our paper shows they are not very effective.

\section{Acknowledgement}

I gratefully acknowledge financia support from the European Commission (HPSE-CT-2002-00146), the Instituto Flores de Lemus and the Spanish Ministry of Science and Technology (SEC2003-03797). I would like to thank Ashish Arora, Elizabeth Cabrera, Marco Giarratana, Arye Hillman, Walter Park, Prabuddha Sanyal, three anonymous reviewers of this journal, and participants at the second RTN Workshop on "Trade, Industialization and Development" (CEPR, London) for comments and suggestions on an earlier draft. 


\section{Appendix A}

\section{A.1. List of countries used in the empirical estimations}

Algeria, Argentina, Australia, Austria, Bangladesh, Belgium, Bolivia, Brazil, Cameroon, Canada, Chile, Colombia, Congo, Costa Rica, Cyprus, Denmark, Ecuador, Egypt, El Salvador, Finland, France, Germany (West), Greece, Guatemala, Honduras, Hong Kong, Iceland, India, Indonesia, Iran, Ireland, Israel, Italy, Jamaica, Japan, Jordan, Kenya, Korea, Malawi, Malaysia, Mauritius, Mexico, Netherlands, New Zealand, Nicaragua, Norway, Pakistan, Panama, Papua New Guinea, Paraguay, Peru, Philippines, Portugal, Senegal, Sierra Leone, Singapore, South Africa, Spain, Sri Lanka, Sudan, Sweden, Switzerland, Syria, Thailand, Trinidad and Tobago, USA, Uganda, Uruguay, Venezuela, Zambia, Zimbabwe.

\section{A.2. Firms of our sample and their nationality}

3M (USA), Abbott (USA), AGA (SWE), Air Liquide (FRA), Air Products (USA), Akzo (NET), Allied-Signal (USA), American Home Products (USA), Amoco (USA), ARCO (USA), Aristech Chemical (USA), Asahi Chemical (JAP), Ashland Oil (USA), Atochem (FRA), Avon (USA), BASF (WGE), Baxter-Travenol (USA), Bayer (WGE), Beecham (UK), BF Goodrich (USA), BOC (UK), Boehringer Ingelheim (WGE), Boehringer Mannheim (WGE), Borden (USA), Borg Warner (USA), BP (UK), Bristol-Myers (USA), Cabot (USA), Ciba-Geigy (SWI), Colgate-Palmolive (USA), Cookson (UK), Courtaulds (UK), Cyanamid (USA), Chevron (USA), Daiichi (JAP), Dainippon (JAP), Degussa (WGE), Dow Chemical (USA), DSM (NET), Du Pont (USA), Dyno (NOR), Eastman Kodak (USA), Eisai (JAP), Elf Aquitaine (FRA), Eli Lilly (USA), EMC (FRA), EniChem (ITA), Ethyl Corp (USA), Exxon (USA), Ferro (USA), FMC (USA), Fujisawa Pharmaceutical (JAP), Gechem (BEL), General Electric (USA), Georgia Gulf(USA), Glaxo (UK), Goodyear (USA), Grace WR (USA), Henkel (WGE), Henley (USA), Hercules (USA), Hoechst (WGE), Hoffmann-LaRoche (SWI), Huls (WGE), Huntsman Chemical (USA), ICI (UK), IMC (USA), Japan Synthetic Rubber (JAP), Johnson \& Jonson (USA), Kanebo (JAP), Kao (JAP), Kemira
(FIN), Kuraray (JAP), Kyowa Hakko (JAP), Laporte (USA), Lonza (SWI), Lubrizol (USA), Lyondell Petrochemical (USA), Merck \& Co (USA), Mitsubishi Chemical (JAP), Mitsubishi Gas Chemical (JAP), Mitsubishi Petrochemical (JAP), Mitsubishi Rayon (JAP), Mitsui Petrochemical (JAP), Mitsui Toatsu (JAP), Mobil (USA), Monsanto (USA), Montedison (ITA), Morton Norwich (USA), Nalco (USA), Neste (FIN), NL Chemicals (USA), Nobel Industries (SWE), Norsk Hydro (NOR), Nova (CAN), Occidental (USA), Olin (USA), ORKEM (FRA), Otsuka (JAP), $P$ \& G (USA), Pennwalt (USA), Perstorp (SWE), Petrofin (BEL), Pfize (USA), Pharmacia (SWE), Phillips (USA), PPG (USA), Quantum (USA), Reckitt \& Colman (UK), Repsol (SPA), Revlon (USA), Rhone-Poulenc (FRA), Rohm (WGE), Rohm \& Haas (USA), Rorer Group (USA), Rutgerswerke (WGE), RWE (WGE), Sandoz (SWI), Sankyo (JAP), Sanof (FRA), Schering (WGE), Shell (UK-NET), Shin-Etsu Chemical (JAP), Shionogi (JAP), Shiseido (JAP), Showa Denko (JAP), SmithKline (USA), Snia (ITA), Solvay (BEL), Squibb (USA), Sumitomo (JAP), Sun (USA), Syntex (USA), Taisho Pharmaceuticals (JAP), Takeda Chemical (JAP), Tanabe Seiyaku (JAP), Teijin (JAP), Tenneco (USA), Texaco (USA), Toray Industries (JAP), Toso (JAP), Toyobo (JAP), Ube (WGE), UCB (BEL), Unilever (UK-NET), Union Carbide (USA), Unitika (JAP), Unocal (USA), Upjohn (USA), Warner-Lambert (USA), Wellcome Foundation (UK), Witco (USA), Yamanouchi Pharmaceutical (JAP).

\section{References}

Aftalion, F., 1991. History of the International Chemical Industry. University of Pennsylvania Press.

Alburquerque, R., 2003. The composition of international capital fl ws: risk sharing through foreign direct investment. Journal of International Economics 61, 353-383.

Arora, A., Ceccagnoli, M., 2004. Profitin from licensing: the role of patent protection and commercialization capabilities. Unpublished manuscript. INSEAD.

Arora, A., Fosfuri, A., 2003. Licensing the market for technology. Journal of Economic Behavior and Organizations 52 (2), 277-295.

Arora, A., Fosfuri, A., Gambardella, A., 2001. Markets for Technology: Economics of Innovation and Corporate Strategy. MIT Press, Cambridge, MA.

Arora, A., Gambardella, A., 1994. The changing technology of technological change. Research Policy 23, 523-532. 
Barro, R., Lee, J.H., 1994. Data Set for a Panel of 138 Countries. Available online at http://www.nuff.ox.ac.uk/Economics/ Growth/barlee.htm.

Bevan, A.A., Estrin, S., 2000. The determinants of foreign direct investment in transition economies. CEPR Discussion Paper No. 2638, CEPR, London.

Branstetter, L.G., Fisman, R., Foley, C.F., 2002. Do stronger intellectual property rights increase international technology transfer? Empirical evidence from U.S. firm-1 vel panel data. NBER Working Paper.

Chemintell, 1996. Chemical Intelligence Services (Chem-Intell). Reed Elsevier Plc Group.

Cohen, W.M., Levinthal, D., 1989. Innovation and learning: the two faces of R\&D. Economic Journal 99, 569-596.

Cohen, W.M., Nelson, R.R., Walsh, J. 2000. Protecting their intellectual assets: appropriability conditions and why U.S. manufacturing firm patent (or not). NBER Working Paper No. 7552. NBER, Cambridge, MA.

Dunning, J.H., 1981. International Production and the Multinational Enterprise. George Allen and Unwin, London.

Erb, C.B., Harvey, C.R., Viskanta, T.E., 1996. Political risk, economic risk and financia risk. Financial Analysts Journal.

Fink, C., 1997. Intellectual Property Rights and U.S. and German international transactions in manufacturing industries. Mimeo.

Flamm, K., 1984. The volatility of offshore investment. Journal of Development Economics 16, 231-248.

Fosfuri, A., 2000. Patent protection, imitation and the mode of technology transfer. International Journal of Industrial Organization $18,1129-1149$.

Fosfuri, A. 2002. Country risk and the international fl ws of technology: evidence from the chemical industry. Universidad Carlos III de Madrid. Working Paper 02-25.

Ginarte, J.C., Park, W.G., 1997. Determinants of patents rights: a cross-national study. Research Policy 26, 283-301.

Greene, W.H., 1993. Econometric Analysis, third ed. Macmillan Publishing Company, New York.

Hill, C.W., Hwang, L.P., Kim, W.C., 1990. An eclectic theory of the choice of international entry mode. Strategic Management Journal 11, 117-128.

Hymer, S.H., 1976. The international operations of national firms a study of foreign direct investment. MIT Press, Cambridge, MA.
Kogut, B., Zander, U., 1993. Knowledge of the fir and evolutionary theory of the multinational corporation. Journal of International Business Studies 24, 625-645.

Lee, J.Y., Mansfield E., 1996. Intellectual property protection and U.S. Foreign direct investment. The Review of Economics and Statistics 78 (2), 181-186.

Markusen, J.R., 1995. The boundaries of multinational enterprises and the theory of international trade. Journal of Economic Perspectives 9, 169-190.

Maskus, K.E., 1998. The international regulation of intellectual property. Weltwirtschaftliches Archive 134, 186-208.

Maskus, K.E., Saggi, K., Puttitanun, T., 2003. Patent rights and international technology transfer through direct investment and licensing. In: Conference on the International Public Goods and the Transfer of Technology after TRIPS. Duke University Law School, 4-6 April 2003.

Motta, M., 1992. Multinational firm and the tariff-jumping argument. European Economic Review 36, 1557-1571.

Oxley, J.E., 1999. Institutional environment and the mechanisms of governance: the impact of intellectual property protection on the structure of inter-fir alliances. Journal of Economic Behavior and Organization 38, 283-309.

Rapp, R.T., Rozek, R.P., 1990. Benefit and costs of intellectual property protection in developing countries. Journal of World Trade 24, 75-102.

Smarzynska, B., 2003. The composition of foreign direct investment and protection of intellectual property rights: evidence from transition economies. European Economic Review 48 (1), 3962.

Smith, P.J., 2001. How do foreign patent rights affect U.S. exports, affiliat sales, and licenses? Journal of International Economics 55, 411-439.

Teece, D.J., 1986. Profitin from technological innovation. Research Policy 15 (6), 285-305.

Wheeler, D., Mody, A., 1992. International investment location decisions. Journal of International Economics 33, 57-76.

Williamson, O., 1991. Comparative economic organization - the analysis of discrete structural alternatives. Administrative Science Quarterly 26 (4), 269-296.

World Investment Report, 2002. Transnational corporations and export competitiveness. UNCTAD. 